\title{
Commentary of the Special Issue in Organization Behavior
}

\author{
Jason D. Shaw
}

Correspondence: jason.shaw@polyu. edu.hk

The Hong Kong Polytechnic University, Kowloon, Hong Kong
The five papers in this special issue are the products of the idea development workshop on Organizational Behavior held by Frontiers of Business Research in China (FBR) at the Renmin Business School (Renmin University of China) in September 2017. In addition to their high quality, the papers represent the variety as well as theoretical and practical value of top-quality studies of behavior in organizations. In this brief commentary, I offer a few comments on each paper and thoughts for future researchers interested in these topic areas.

The first paper by Shanshan Wen ("The effect of result publicity on self-serving attributional bias $-A$ social comparison perspective") offers new insights on one of the linchpin theories in the field-attribution theory. Although there are nuances, the theory suggests generally that people attribute successes to internal factors (e.g., intelligence, effort) and failures to external factors (e.g., others' influences, bad luck). But, as Wen highlights, the extant findings provide only mixed support for external attributions after failures. Wen argues that whether the failures are public explains the discrepancy. When failures are public, individuals tend to make external attributions, but in the absence of public exposure, tend to make internal attributions. There are several implications of this research for future researchers. One potential impactful one is where these results dovetail with escalation of commitment or sunk-cost-effect research. Public exposure of poor prior decisions may lead to escalation not because of framing (a prospect theory explanation) or face-saving (a psychological explanation), but rather because decision makers may believe that external factors, rather than decision errors, were the cause of prior failures.

In Lin and Sun's article ("Chinese employees' leadership preferences and the relationship with power distance orientation and core self-evaluation"), the authors examine an age-old question about leadership style in China. Challenging and extending current assumptions, they find that Chinese employees indicate preference for a moral leadership style, but are also influenced by transformational leader behaviors. They also find some individually different moderators, but the preference data is clear and compelling and suggests a rethinking of the view that Chinese employees respond mostly favourably to a paternalistic leadership style comprising moral, benevolent, and authoritarian facets.

Wang and Li examine the potential downsides of having a high-quality relationship with your supervisor ("You don't actually want to get closer to the star: How LMX leads to workplace ostracism"). They argue that being close to one's supervisor creates envy among coworkers, and further, especially when the employee is low in

(c) The Author(s). 2018 Open Access This article is distributed under the terms of the Creative Commons Attribution 4.0 International License (http://creativecommons.org/licenses/by/4.0/), which permits unrestricted use, distribution, and reproduction in any medium, provided you give appropriate credit to the original author(s) and the source, provide a link to the Creative Commons license, and indicate if changes were made. 
agreeableness, that envy from others leads to ostracism. These results add to the complex literature on the causes and consequences of envy and will contribute to the growing literature on the downsides of positive relationships at work.

Yu and Li ("Childhood economic status predicting later income: The role of networking ability and encouragement of participation") offer new insights on the relationship between childhood privilege and career success. Taking a new view, they argue that the advantages to career success may accrue via social-capital-accrual success rather than other advantages of childhood family wealth. The study shows that family wealth predictes later income mediated by social capital. The ideas are provocative, although the crosssectional design is not able to pin down the causal mechanisms at issue in the theory. Certainly, future researchers can explore these ideas with alternative designs.

In the final paper, Zhang et al. ("How authentic leadership influences employee proactivity: The sequential mediating effects of psychological empowerment and core selfevaluations and the moderating role of employee political skill") examine the relationships among leadership, proactivity, and other explanatory variables. In my view, the finding is that authentic leadership relates to higher empowerment and the later to more proactive behaviors. The moderator, political skill, offers additional explanatory power, but the key takeaway is that employees respond in favourable ways to leaders that behave in authentic ways in Chinese contexts and act in positive proactive ways as a result.

Received: 23 March 2018 Accepted: 26 March 2018

Published online: 16 April 2018

\section{Submit your manuscript to a SpringerOpen ${ }^{\circ}$ journal and benefit from:}

- Convenient online submission

- Rigorous peer review

- Open access: articles freely available online

- High visibility within the field

- Retaining the copyright to your article

Submit your next manuscript at $\gg$ springeropen.com 